\title{
Democracy and Rural Development in Nigeria's Fourth Republic: Challenges and Prospect
}

\author{
Abdulrazak Yuguda Madu1 \\ Rohana Yusof2 \\ Suyatno ${ }^{3}$ \\ ${ }^{1}$ Ghazali Shafie Graduate School of Government, Universiti Utara Malaysia, 06010 Sintok, Kedah, Malaysia \\ ${ }_{2}^{2}$ Northern Corridor Research Centre (NCRC), Universiti Utara Malaysia, 06010 Sintok, Kedah, Malaysia \\ ${ }^{3}$ School of Government, College of Law, Government and International Studies, Universiti Utara Malaysia \\ 06010 Sintok, Kedah Malaysia; Corresponding author: abdurrazakmadu@yahoo.com
}

\section{Doi:10.5901/mjss.2015.v6n6s4p445}

\begin{abstract}
Nigeria's return to democratically elected government in 1999; after decades of Military rule and dictatorship since independence in 1960 has placed the country's agenda on an agreed target by all and sundry, and this was accompanied by hopes, aspirations and expectations, due to the fact that, the countries development remains inadequate, most especially at the rural level which is regarded as most deprived and undeveloped. This paper therefore, attempts to examine the challenges and prospects of democracy on rural development in Nigeria from 1999-2014. The methodologies adopted in obtaining data for the paper are purely empirical and secondary. The paper contends that, democratic performance to bringing the desired changes and development in Nigeria remained abysmal and insignificant. It was concluded that for democracy to be meaningful; rural dwellers which accounted for the bulk of the country's population must be developed otherwise the counties strides to been among one of the developed nations will remain a mirage and unattained.
\end{abstract}

Keywords: Democracy, rural development, Nigeria's Fourth Republic, challenges \& prospects.

\section{Introduction}

Democracy as a system of government is now becoming a household name in Africa and Nigeria in particular. This is in the sense that, many African states are now becoming democratic and indeed a republic, contrary to militarization of the governmental structures in most of the African states particularly from 60's and 70's, although to 90's. Perhaps, this is as a result of its perceived principle which is said to be the government that represents peoples' interest; that is, the government of the people by the people and for the people. It is also seems to be the only means of governance that appeals to all and sundry. Nigeria is one of these countries that practices democratic system and this was successfully enthroned in 1999; which ushered in the Fourth Republic. Nigeria's successful transition from military rule to an elected civilian government in 1999 has placed democracy on the country's agenda as an agreed target by all, and this was accompanied by hopes, aspirations and expectations, due to the fact that, the countries development remains inadequate, most especially at the rural level, which is regarded as most deprived and undeveloped.

Studies in human settlements distribution in Nigeria shows that, majority of the Nigerian populace; over $60 \%$ live in the rural areas with attendants' socio-economic problems. This is corroborated by Otaki (2005) in which he argues that, it is estimated that about seventy per cent (70\%) of the population of Nigeria and other underdeveloped countries live in rural areas. From these therefore, suffice it to say that, every responsible government most especially the democratically enthroned one should be responsive to meet the yearnings and aspirations of the teaming rural-folks. Yet, in spite these however; rural studies have shown that, the rural areas in Nigeria had suffered many years of neglect. The little that has been put in place by successive governments in terms of infrastructural facilities was mostly in favour of the urban centres to the neglect of the rural areas. It is in this light that (Ezeah, 2005) observes;

The Nigerian rural areas are neglected areas, even though social services are also not adequate in some urban areas. The situation in the rural communities is far worse that many communities lack basic amenities.....

This paper therefore, discusses democracy and rural development in Nigeria with a view to expose some of the challenges of democracy in Nigeria to achieving effective rural development and proffer some of the likely prospects. The 
paper is structured into the following: Introduction, conceptual explication, methodology, the challenges of democracy and rural development in Nigeria, prospects of Nigeria's democracy on rural development and lastly made conclusion.

\section{Conceptual Explications: Democracy and Rural Development}

\subsection{Democracy}

Democracy is a concept that suffers from conceptual interrogation, because many scholars and researchers have attempted defining it differently on different perspectives. Bello, (2011) maintained that most of the components of modern democracy were founded in ancient Greece and further argues that, it seems to be the only means of governance that appeals to all and sundry in both the advanced countries as well as the underdeveloped ones. This could be because of the room it gives for people's participation in the restoration, operation and sustenance of government. From a theoretical focus democracy according to Yusif, (2009) can summed up to be a system that emphasizes on collective engagements to accomplishing the citizen's aspirations according to the rules of the game for their common goal. It is also fundamental that through democracy people come to make rules that would enable the political system to provide growth, fairness and equity as well as other goals we share in common between various ethnic and social groups.

Otive, (2011) on his own part says, democracy is only meaningful if it delivers in bringing socio-economic development to the nation. It was further argued that the political freedom which forms the basis of democracy remained insignificant without commensurate socio-economic development that will uplift people from hunger, deprivations and degradations. Hence, the need for people to elect leaders in order to respond to their myriads of problems bedevilling them.

From the above, it could be deduced that democracy entails to be a system with adequate institutional capacity and structures that allows for broader sovereignty to the people and guarantee them human rights with dignity. Unfortunately, this conception of democracy is narrow on its focused as it only emphasized on political aspect and process of democracy without commensurate socio-economic considerations that betters human existence. This is because in practical democracies like in Africa, and Nigeria in particular poverty and deprivations of necessities of lives particularly to the vulnerable rural people often prevents the mass of the people from actualizing and enjoying their political and civic rights while the concentration of wealth in the hands of a few, gives the economically-privileged minority uninterrupted political influence.

Viewing from different perspective, Ternande, (2003) sees democracy as the political and economic empowerment of the majority of the ordinary people to participate in the decisions that has bearings to their lives, their individual and collective rights and the way in which their society is governed. This is in contrast to the practical democracy been practiced in Nigeria. This was corroborated by Victor and Allen (2009) that democracy in Nigeria is far away from people's welfare; as citizens were neglected from its benefits. This shows the high level of irresponsibility of any government; to talk of the democratic system of government. The system that was correctly described by Okeke, (2014) as "ceremonial democracy". This seems to be so as leaders are only elected to fill the public offices without commensurate performance to meeting the yearnings and aspirations of the people.

\subsection{Rural development}

Over the years rural development has been considered a veritable tool for enhancing development; particularly in the developing and undeveloped societies. It is basically, concerns about a review and assessment of the improvement in the quality of life of rural people; which is broadly measured with the sufficient provision of health and social services, good living conditions and bridging of income inequalities amongst others. These leads to universal concerns that, rural development rests upon the improvement of quality of life of the rural populace.

Idris, (2011) sees rural development as a continued set of actions by government agencies, NGO's and the rural populace to improving the living conditions of the rural people and also as a process which lead to series of changes within the confine of a given rural setting and which eventually result in the improvement in the general conditions of the rural dwellers. The changes in living conditions depend on a variety of factors such as improvement in education, health, water supply, feeder road networks, electrification amongst others. Provision of these means democratic dividends in the Nigerian democracy. This is because, they all constitutes campaign promises and political manifestos of elections campaigns in Nigeria.

Rural development is a comprehensive mode of social transformation, a socio-economic change seeking to bring 
about more equitable distribution of resources within the society, and a veritable acceptance of the principle of growth from below. This emphasized on the need to ensure socio-economic balance and equitable distribution of wealth and resources among people and among the rural populace. Failure to do so makes an economy yet underdeveloped. Nigeria for example experienced an unprecedented economic growth in recent times; but without commensurate development. Currently, (2014) World Bank rated Nigeria as the biggest economy in Africa but yet, among the poorest countries globally. This proves the claims that although the country is rich and the economy is growing, still majority of its population are poor. These pose a great challenge to the managers and drivers to the economy. The only way is to ensure equitable distribution among people and among the sectors and ensure that the growth witnessed by the economy is all inclusive. In the real sense of things, failure to involve the rural populace in carrying out developmental projects in their localities in the name of rural development usually leads such projects to become a wasted effort and this happens not only in Nigeria, but in other countries both developed and third world countries.

Looking at it from different perspective, Ndangra, (2005) maintains that, rural development is broadly seen as an integrated process involving the implementation of sectoral programmes and provision of social services under the surveillance and the full participation of the major relevant stakeholders. That, it is also, an educational process which seeks to create opportunities for rural people to satisfy their human, economic, social and psychic needs. This shows that, the success of rural development lies in implementation of the programmes and policies initiated. This has been the problem in Nigeria; in the sense that successive government came up with various programmes that were laudable but marred with implementation problems which left rural communities undeveloped.

\section{Methodology}

The methodology adopted for this paper is purely secondary sources and empirical data obtained from literatures and internet sources that address issues on democracy and rural development in Nigeria and content analysis method were also used. According to Steve (2001) "content analysis enables researchers to sift through large volumes of data with relative ease in systematic fashion. It is also useful for examining trend and patterns of phenomenon in literatures".

\section{Democracy and Rural Development in Nigeria: Challenges and Prospects}

Nigeria is structured into 36 states and Federal Capital Territory, Six Geo-political zones and 774 Local Government Areas. Most of these states experienced most critical challenges on issues of development. It is also said that many states, particularly states at Northern region are most rural, and underdeveloped which placed them below in terms of all developmental index and measure; thereby becoming the most vulnerable that requires serious attention most especially under current democratic arrangements.

Rural development is that aspect of development concerned with an improvement on the living conditions and welfare of the rural populace. Democracy remains the system of government that responds to the yearnings, living conditions and welfare of the citizenry. This indicates that, for democracy to be meaningful, considerable attention must be paid to bringing development especially at rural level. Although, rural sub-sector in Nigeria had witnessed considerable attention in terms of policy pronouncement and commitments by successive government over times. But still marred with numerous challenges and problems that leaves much to be desired in terms of its development. This paper found some of the following as major challenges of democracy to rural development in Nigeria.

\subsection{Challenges of High Rate Poverty}

According to the Department for International Development (2014) Nigeria has a quarter of Africa's extreme poor, with about 100 million of a population of 174 million living on less than $£ 1$ a day. The incidence of poverty in Nigeria is quite alarming that an average man finds it difficult eating at least three square meals a day. The Northern zones has the most significant challenge in that respect, in the sense that recent statistical survey conducted by the National Bureau of Statistics (2012) indicated that, North-Central zone recorded 59.5\%; North-East 69\%, North-West 70\% with people that are absolutely poor, and most of them were drawn from the rural communities with attendant socio-economic problems, and this is quite alarming as compared for instance to its counterpart in the southern zones that recorded as follows; South-East 58\%, South-South $55.9 \%$ and South-West $49 \%$ poverty level respectively. The incidence of poverty in the country in terms of human settlement is $33.9 \%$ urban and $66.1 \%$ rural. This shows that Nigerian democracy has a great challenges of tackling this ugly menace and emancipate its people from the shackles of been absolutely poor to a happy and wealthier society. 


\subsection{Inadequate Rural Roads}

The country has enormous economic potentials, most especially in agriculture and other mineral resources, which are mostly located and found in rural areas. Nevertheless, these abundant resources have not been accessed and fully harnessed due to inadequate and absence of rural roads. Most of the communities are left unconnected, in limbo, agony and terrible conditions. Rural roads need to be provided and properly connected so that the agricultural and other mineral resources be extracted and exploited to bring meaningful development not only to the communities but to the nation at large. This poses a serious challenge on democratically enthroned government.

\subsection{High Rate of Illiteracy}

Illiteracy is one of the major problems of Nigeria, due to the fact that, many people especially children are out of school and leaving many states with a very low school enrolments. For example; based on the National literacy survey of National Bureau of Statistics (2010) the youth literacy rate who are regarded as bedrock of any society goes as follows according to the English and any other language respectively in percentage in at least sample of six (6) states in the North two each from each of the zones and Sample of one (1) state in each of the southern zones clearly show as follows: NE, Bauchi 39.5; Gombe 45.6 and 69.8; NW, Katsina 55.1 and 63.6; Kebbi 52.3 and 71.1, NC, Nasarawa 62.9 and 66, Niger 58.3 and 63.9 while, In the southern part samples of for example, SW, Lagos; 95.1 and 96.5, Ogun; 90.4 and 93.8, SE, Imo; 95.5 and 96.1, Ebonyi; 91.9 and 92, SS, Edo; 89.7 and 89.9, Bayelsa; 93.8 and 93.8.

Generally, according to BTI (2014) in Nigeria, the education index is 0.422 and the literacy rate is put at $60 \%$. Inadequate education is reflected by very poor scores of just 0.648 and by a school enrolment of $53 \%$, although government expenditure on education is $10 \%$ of the current annual budget. The threatening north-south dichotomy in all social and economic sectors is significantly illustrated by the current state of this sector. Interestingly, school enrolment in the south gets to some $70 \%$, while in the poverty-stricken north only some $30 \%$ go to school. It is important to note that, illiteracy is more pronounced at the rural areas in Nigeria. These; calls for urgent attention and concern.

\subsection{Challenges of Corruption in Governance}

The challenge of Corruption is one of the factors behind the endemic social challenges in Nigeria. According to the Transparency International (2013) Nigeria is one of the most corrupt countries in the world, ranked 144 of 177 countries with a score of 25 out of 100 . The political leaders in Nigeria always take the advantage of their political power and loot government treasuries at the expense of developmental programmes. This is prevalent at all levels of government. This is in line with Persson's (2014) statement that 'Corrupt practices are thus prevalent throughout Nigeria, from the highest political level to local government officials. For examples a lot of monies were earmarked either by the government or international rural intervention agencies on various programs aimed at solving rural problems but the said monies were said to be diverted for private gains. It is in this light that, Persson further says 'Underdevelopment, lack of education and health services and malfunctioning service delivery in general are closely interconnected with the widespread corruption in Nigeria. These pose a serious challenge to democracy in Nigeria.

\subsection{Policy Inconsistency and Poor Implementations}

Rural development in Nigeria has suffered from persistent policy summersault and changes by successive governments. Successive governments came up with different policies and programmes, which usually ends at the expiration of their regimes without continuity. In most cases, the policies initiated are not properly implemented without making any impact. It is in this light that, Ugwuanyi and Chukwuemeka (2013) says:

Nigeria has over the years, developed various policies to enhance the development of the rural areas. Realizing the development of those policies and programs has, however, been constrained by the pattern and nature of their implementation which was characterized by ineffectiveness and inefficiency.

The above challenge constitutes a serious one for any serious and responsible government. This is in the sense that, whatever laudable a program or a policy, without been consistently pursued and properly implemented yield no impact. It is said that, the success of policies begins and ends in its implementation. 


\subsection{Unpopular Government and Imposition of Leaders}

Democracy is all about people. The leaders should therefore be elected by the people to represent them in government. That makes the government popular and thereby enjoyed absolute loyalty from the electorates. In Nigeria however, it is observed that, most of the leaders in government under the current democratic dispensation are not elected by the people but rather been imposed by the political leadership either because they are from the ruling party or because of their economic status. This makes it difficult for the leaders to deliver in terms of development and leaves especially the rural populace in serious states of underdevelopment. For example, after 2007 general election that brought the then YarAdua/Goodluck administration, International election observers frowned that the election was marred with sorts of irregularities. This was confirmed by the YarAdua himself at his acceptance speech in National broadcast.

The imposition of leaders on people in Nigeria is more pronounced especially at the grassroots democracy. This is in the sense that, many states government in Nigeria finds it difficult to conduct Local government elections (to produce the government that is usually at the rural areas and at grassroots levels). The appointments of representatives of local people are usually been done by the state Governors (which is unconstitutional); in which the Local Government Chairperson's and Councillors are appointed as caretakers by the state Governors and the appointed Chairmen nominates his/her supervisory councillors. Where elections are conducted, the ruling party in that states (whether ruling party or opposition) usually produced all the elected officers through rigging, and other electoral malpractices. All these affect effective delivery of services at the rural level of Nigeria.

\section{Prospects of Nigerian Democracy on Rural Development}

It was clearly shown from the above analysis that, the democratic practice in Nigeria is faced with numerous challenges against rural development; yet this paper is still optimistic that all hopes are not lost. The following may be a prospect in Nigerian democracy to foster development in rural areas:

\subsection{Public/Community Awareness and Consciousness on their rights}

The ever increasing consciousness and awareness of Nigerian people on their rights and understanding the tenets of democracy may serve as prospect to rural development in Nigeria. It is observed that, in Nigeria many people and communities are becoming conscious and aware of their rights and the roles expected of government on the electorates and start putting more pressures on government to act accordingly. This is usually done through Community Based Organizations (CBOs), enlightened individuals and other pressure groups. This is the development in the right direction, as it will gradually continue to have impact on drawing leader's attention to acts on community and rural demands, thereby bringing development. One of the examples of such is the mass protest by people across the country against fuel subsidy removal on $16^{\text {th }}$ January, 2012, which followed after the $9^{\text {th }}$ January, 2012 national strike action organised by the Nigerian Labour Congress (NLC). The government argued that, with the removal of fuel subsidy, it will realise enough money to finance badly needed public projects across Nigeria especially in roads constructions/rehabilitations, electrifications, water supply etc. But however, people became apprehensive and remain suspicious of government due to corruption in governance overtime, which makes it difficult by the political leaders to even implements budgets on the said projects. Majority felt that, this is another avenue to loot their resources, thus protest against.

\subsection{Global calls for Transparency and Accountability in Governance}

Nigeria has the potential of becoming one of the developed countries in the world, but corruption and other factors held the country's economy to ransom; as highlighted earlier. However, with the adoption of democracy, more is expected from the elected leaders to be accountable and transparent, which serves as the major indicators of good governance. The Nigerian government also, in order to respond to that establishes agencies and enact some enabling laws to checkmates abuses in government and ensure transparency and accountability. For example, the Bureau for Public Procurement (BPP) was established, Code of Conduct Bureau (CCB), and anti-graft agencies like the Economic and Financial Crimes Commissions (EFCC), Independent Corrupt Practices and other Related Offences (ICPC) and other enabling laws and Acts like Freedom of Information Act (Fol) and Public Procurement Act (PPA) etc. While at the International level the Transparency International and other leading Institutions emphasised on all these for transparent and accountable governments across the globe. 


\subsection{Building of Strong Opposition Party and Calls for Free and Fair Elections}

Democracy in Nigeria is becoming stable with strong opposition base. Recently, Nigeria recorded an unprecedented merger of mega opposition parties meant to challenge the rots and decayed in Nigeria's democratic process and service delivery. About four leading opposition parties; Action Congress of Nigeria (ACN), All Nigerian Peoples Party (ANPP), All Progressive Peoples Grand Alliance (APGA) and Congress for Progressive Change (CPC) were merged; the first of its kind in the history of Nigerian politics. Pundits and academics sees this development as a victory for democracy as it will strengthened governance and calls for more transparency that will usher in development.

More ever, the strong calls for free and fair elections in Nigeria is another issue of concern by not only the opposition parties but the general public as well. In recent elections, people developed some concepts of voting and protecting the votes cast in Nigeria particularly in the Northern parts of the country as the result of incessant rigging and declaring unpopular candidates in power. The slogans in Hausa language 'A kasa, a tsare, a raka' literarily meaning 'Cast your votes, protect your votes and accompany it' was developed and taken seriously by the electorates. This is the practice that may make the leaders understand that, the masses are now aware of their right and need honest, accountable, and transparent leaders to be voted in order to respond to their myriads needs especially rural needs.

\subsection{Proliferations of Non-governmental Organizations and International Agencies}

The government commitments in partnering with the private sectors, Non-governmental organizations and International agencies and ever increasing presence and role been played by them in rural development is another development in the right direction. This will complements the government efforts in development of rural communities in Nigeria in the future.

\section{Conclusion}

It was established that, rural dwellers constitutes bulk of Nigeria's population and required greater attention from the democratic government in meeting it myriads problems. This is evident from the fact that, democratic governance stands for people. The paper confirms that, democratic performance to bringing the desired changes and development in rural Nigeria remained abysmal and insignificant and found amongst others that, rural poverty, illiteracy and corruption in governance and policy inconsistency and implementation remains the major challenges on democracy to bringing the desired transformation and rural development in Nigeria. It is concluded that for democracy to be meaningful; rural folk must be developed otherwise the counties strides to been among one of the developed nations will remain a mirage and unattained.

\section{References}

Adeyinka, T.A and Emmanuel, 0.0 (2014) Democracy in Nigeria: Practice, Problems and Prospect, Developing Country Studies; 4 (2), 107-125.

Akpan, N.S. (2012) From Agriculture to Petroleum Oil Production: What has Changed about Nigeria's Rural Development? International Journal of Developing Societies, 1(3), 97-106.

Bertelsmann Stiftung, BTI 2014 - Nigeria Country Report. Gutersloh: ..... Corruption and White-Collar Crime are Widespread at Every Level. Retrieved 05/09/2014 @ www.bti-project.de/uploads/tx_itao_download/BTI_2014_Nigeria.pdf

Bello, K. (2011) Resurgence of Democracy and its Impact on Good Governance in Africa, in Researchers World Journal of Arts, Science and Commerce, Vol-II, Issue-2, 51-58.

Corruption Perceptions Index 2013 www.transparency.org

DFID (2013) Anti-corruption Strategy for Nigeria, Department for International Development, UKaids, retrieved 10/09/2014 @ www.dfid.gov.uk/Nigeria.

Ezeah, P. (2005) Rural Sociology and Rural Development with Focus in Nigeria; John Jacob Classic Publishers, Enugu.

Idris, S. (2011).The Role of Kaduna State Ministry for Rural and Community Development in Rural Development in Some Selected Rural Communities of Kaduna State, An Unpublished MS.c Public Administration, Thesis, Postgraduate School, A. B. U. Zaria, Nigeria.

John, C. (2001) Local Democracy, Democratic Decentralization and Rural Development: Theories, Challenges and Option for Policy, Development Policy Review, 19 (4): 521-532.

NBS, (2010). Annual Abstract of Statistics. Abuja: NBS Publishers

NBS, (2010). National Literacy Survey, retrieved 27/08/2014 @ www.nigerianstat.gov.ng/papes/downloads/43

Okeke, R.C. (2014) Democracy and Sustainable National Development in Nigeria: Reimagining the Nexus, European Scientific Journal, 10 (1), 229-249.

Oruonye, E.D. (2013) Grassroot Democracy and the Challenges of Rural Development in Nigeria: a Study of Bali Local Government 
Area of Taraba State. Asian Journal of Humanities and Social Sciences, 1(1), 12-19.

Otaki, A.O. (2005); Rural Sociology: An Introduction, Joyce Graphic Printers and Publishers Company, Kaduna.

Otive, I. (2011) Perspective on Democracy and Development in Nigeria. Retrieved 09/04/2014 @ http://www.gamji.com/article4000/ NEWS4733.htm

Persson, H. (2014) Nigeria-An Overview of Challenges to Peace and Security, retrieved 05/09/2014 at www.foi.se/.../Persson,\%20 Nigeria\%20\%20An\%20Overview\%20of\%20...

Steve, S. (2001). An Overview of Content Analysis. Practical Assessment, Research \& Evaluation, 7(17). Retrieved 20/09/ 2015 @ http://PAREonline.net/getvn.asp?v=7\&n=17.

Ugwuanyi, B.T and Emma, E.O.C (2013) Enhancing Rural Development in Nigeria: Periscoping the Impediments and Exploring Imperative Measures, Kuwait Chapter of Arabian Journal of Business and Management Review, 2(7), 91-101.

UNICEF (2013) Nigeria Country programme document 2014-2017 - Unicef retrieved 05/09/2014 @ www.unicef.org/nigeria/2013-PL7Nigeria_CPD-final

Victor, O. and Allen, F. (2009) From Authoritarian Rule to Democracy in Nigeria: Citizens' Welfare; a Myth or Reality? Journal of Alternative Perspective in Social Science, electronic; 152-192.

World Bank (2013) Nigeria Economic Report - Open Knowledge Repository Retrieved 09/10/2014 @ https://openknowledge.worldbank. org

Yusif, M.M (2009) Democracy Development in Nigeria: The Role of the Legislature, Being a paper presented in a Training Workshop organized by Society for Youth Awareness and Health Development (SYAHD) on Sustainable Democratic Governance in Nigeria held on Sunday May 10th at Mambayya House, Kano. 